\title{
EFFECT OF LIQUIDITY MANAGEMENT ON THE FINANCIAL PERFORMANCE OF BANKS IN NIGERIA
}

\author{
Wuave, Terseer \\ Federal University of Agriculture Makurdi, Benue State, Nigeria. \\ Wuaveterseer@gmail.com
}

Yua, Henry

Banking and Finance Department, Nigerian Army College of Environmental science and Technology, Makurdi Benue State, Nigeria

henryyua@yahoo.com

Yua, Paul Mkuma (PhD)

Graduated from Banking and Finance Department, Nmandi Azikiwe University, Awka

Anambra State, Nigeria

yuapaul@gmail.com

\begin{abstract}
This study examines the effect of liquidity management on financial performance of banks in Nigeria for the period 2010 to 2018. The study uses secondary data from five banks listed bank on the stock exchange in Nigeria. The proxies employ for liquidity management are; Liquidity ratio (LQR), Loan to deposit ratio (LDR), Cash reserve ratio (CRR) and deposit ratio $(D R)$, while return on assets $(R O A)$, return on equity $(R O E)$ and return on net interest margin (NIM) are proxies for financial performance (Profitability). The study uses panel regression analysis in estimating the model and Hausman test while making a choice between fixed effect and random effect model. The study finds that liquidity ratio (LQR) have positive and significant effect on financial performance of DMB as measured by return on assets (ROA), return on equity (ROE) and net interest margin(NIM).It therefore recommends that banks in Nigeria should establish sound governance and risk management systems by developing strategies, policies for liquidity management that is well integrated into its risk management practices as well as establish a contingency funding plan to address any liquidity shortfall during periods of stress or emergency while ensuring that active monitoring liquidity funding needs to avert any liquidity challenge that could trigger crisis in the banks is promptly addressed.
\end{abstract}

KEYWORDS: liquidity management, profitability, banks

\section{INTRODUCTION}

The importance of an effective liquidity management in the banking industry and financial markets cannot be overemphasized. The relevance of liquidity management became pronounced during the 2007-2008 global financial crisis when the banking industry came under severe liquidity strain and stress. During the crisis, it was apparent that liquidity can evaporate like a mirage, but illiquidity can last for an unforeseen or longer period than anticipated. 
Liquidity is the ability of a bank to fund increases in assets and meet obligations as they come due, without incurring unacceptable losses while effective liquidity risk management helps ensure a bank's ability to meet cash flow obligations, which are uncertain as they are affected by external events and another agents' behavior. Liquidity risk management is of paramount importance because a liquidity shortfall at a single institution can have system-wide repercussions (BCBS, 2008). In carrying out the role of financial intermediation especially as it relates to maturity transformation of short-term deposits into long-term loans, banks are inherently exposed to liquidity risk both at an idiosyncratic (institution-specific) level or system-wide.

Anyanwu, (2003) posits that liquidity shortage, no matter how small, can cause unimaginable disruption to a financial institution's operations and customer's relationship. Every business relies on its customers to succeed, therefore managing good customer relationships is key and should be incorporated into its strategic planning process. Liquidity crisis, if not properly managed can result to reputational risk including bad press releases against the institution and could destroy customer's relationships built over the years. In order to avoid this, it is thus imperative that the managers of businesses and financial institutions should have a well-defined business policy and established procedures for measuring, monitoring, and managing liquidity. Managing liquidity is therefore a core daily process requiring institutions to monitor and project cash flows to ensure that adequate liquidity is always maintained to meet their obligations as they arise.

The provision of maintaining adequate liquidity always to meets customer's obligation is an essential feature of banking. Therefore, banks must ensure that adequate provision of cash and other near cash securities are made available to meet daily withdrawals obligations and new loan demands by customers in need of liquidity. It is in this regard that banks in Nigeria are statutorily required to comply with the Cash Reserve Requirement (CRR) policy of the Central Bank of Nigeria $(\mathrm{CBN})$ as well as other regulatory measures of effectively managing their liquidity positions.

There is consensus in theoretical literature that profitability and liquidity constitute the most prominent issues in corporate finance. While it may be true that the goal for any firm is to maximize profit, too much attention on profitability may lead the firm into a pitfall by diluting its liquidity position (Niresh, 2012). Therefore, the need to strike a balance between the firm's desire to make profit and remain liquid cannot be over-emphasized; hence the need for effective liquidity management. It has been argued by scholars that some banks failures have been attributed to poor liquidity management. Some studies have also linked poor liquidity management as a major contributing factor to the Global Financial crisis of 2007-2008 (Adalsteinsson, 2014).

Arising from the above, the study sets out to examine the effect of liquidity management on the financial performance of banks in Nigeria.

\section{Theoretical Framework and Empirical Literature}

\section{Theoretical Framework}

The reconciliation of the conflicting objectives of liquidity and profitability of banks is so apt that, failure to find a balance can lead to crisis of confidence from customers. Theoretically, 
there are many theories that try to resolve this age long problem, they include: Anticipated Income Theory, Liability Management Theory, Commercial Loan Theory and Shiftability Theory. This study however is anchored on the shiftability theory.

\section{Shiftability Theory}

The theory states that a bank's liquidity is adequately maintained if it holds assets that could be shifted or sold to other lenders or investors for cash even during period of crisis or distress. The shiftability theory focuses on the liability side of the balance sheet. The theory contends that supplementary liquidity could be derived from the liabilities of a bank, therefore, shiftability, marketability or transferability of a bank's assets is a basis for ensuring liquidity. The theory further contends that highly marketable security held by a bank is an excellent source of liquidity. The proponents of this view argued that a bank's liquidity could be enhanced if it holds specified liquid assets required to sell to the Central Bank and the discount Market (interbank window) provided they are ready to purchase the asset offered at discount.

According to Nwankwo (1991) argues that since banks can buy all the funds they need, there is no need to store liquidity on the asset side (liquidity asset) of the balance sheet. It pertinent to note that liquidity management theories have been subjected to critical review by various scholars. The general consensus however is that during period of distress or crisis, banks with grave financial conditions and downgraded status may be challenged in obtaining the desired liquidity because the investors/deposits confidence in them has been eroded. This is however not the case with healthy or financially sound banks, which liabilities (deposits, market funds and other creditors) constitute a major component of their liquidity sources as their liquidity strain may be less severe.

Dodds (1982) posits that liability management theory consists of the activities involved in obtaining funds from depositors and other creditors and determining the appropriate mix of funds for a bank. He argues that to ensure convertibility without delay and appreciable loss, such assets must meet three requisites and sought answers to the following questions: how do we obtain funds from depositors? How do we obtain funds from other creditors? What is the appropriate mix of the funds for any bank? He concluded that management should examine the activities involved in supplementing the liquidity needs of the bank through the use of borrowed funds.

\section{Empirical Literature}

Empirically, facts from previous studies linked liquidity management and financial performance of Deposit money banks in Nigeria.Takon and Mgbado (2020) examines the impact of liquidity on banks' profitability using liquid assets, bank deposit, treasury bills, and return on asset as proxies. Secondary data was source from the Central Bank of Nigeria statistical bulletin. The study employs Ordinary least square using multiple regression techniques. The study finds that there is a: positive and insignificant impact between bank deposit and return on asset; negative and insignificant impact between liquid asset and return on asset; and positive and insignificant impact between treasury bills and return on asset. The study recommends that appropriate measures should be taken to prevent undesirable market development that may negatively impact on bank deposit; and also the recruitment of competent and qualified personnel to manage and maintain optimal level of liquidity. 
Otekunrin, Fagboro \& Femi (2019) examines the performance of selected quoted deposit money banks in Nigeria and liquidity management of 17 deposit money banks listed on the Nigerian Stock Exchange (NSE) between 2012 and 2017, the study extracts secondary data the financial statements of 15 deposit money banks for six years and analyze the data using ordinary least square method (OLS). Capital ratio (CTR), current ratio (CR) and cash ratio (CSR) were proxies for liquidity management while performance proxies was return on assets (ROA). The study find that liquidity management and bank's performance are positively related and concludes that liquidity management is an essential factor in business operations and consequently leads to business profitability. It therefore recommends that proper liquidity management would assist in solving the agency theory problem of agency costs that arise when control of companies is separated from the ownership.

Bassey and Ekpo (2018) investigates the critical role played by the CBN and DMBs in fashioning out appropriate framework for liquidity management and identifies the challenges inhibiting effective performance of these roles. The study employs descriptive research design and find that deposit liabilities constitutes a major source of funding liquidity by DMBs while loans and advances constitutes the bulk of the illiquid assets. It also finds that DMBs in Nigeria operates above solvency level, having current ratio greater than unity and are over cautious, investing more in short-term securities to protect their liquidity positions. The study therefore recommends that DMBs should strengthen their credit risk assessment mechanism so as to increase their credit exposure to the private sector and concluded that DMBs should establish a robust liquidity risk management framework that is well integrated into the bank-wide risk management process and ensure that competitive pressures do not compromise the integrity of their liquidity risk management framework, control functions, limit systems and liquidity cushion.

Onyekwelu, Chukwuani and Onyeka (2018) examines the effect of liquidity on financial performance of deposit money banks in Nigeria for the period 2007-2016 using secondary data from five banks. The study employs multiple regression analysis and found that Liquidity has positive and significant effect on both banks' profitability ratios and on Return on Capital Employed. The study recommends that; in addition to investing in human capital, banks should create fora where they sensitize their customers on variety of activities they indulge in that are capable of hindering effective liquidity management and the regulatory authority should put in place appropriate policy measures to ensure compliance and check high volume cash transaction handling and hoarding prevalent in the economy. The study concluded that the Central Bank of Nigeria should critically review and monitor the effectiveness of the implementation of its liquidity policy tools in banks to achieve the desired liquidity level and where necessary impose appropriate sanctions on erring banks.

Obi-Nwosu, Okaro and Atsanan (2017) examines the effect of liquidity management on the performance of DMBs in Nigeria from 2000 to 2015. The study employs Augmented Dickey Fuller Unit Root Test, OLS regression and Granger Causality. The study finds that liquidity mechanism is not significantly related to DMBs performance in the short run and long run and also find that liquidity mechanism granger cause DMBs performance within the period under review in the study. Hence, the study recommends that DMBs should be given leverage of plugging back funds into investment to booster profitability while maintaining a level of liquidity ratio. 
Bassey (2017) investigates liquidity management and performance of Deposit Money Banks (DMBs) in Nigeria from 1986 to 2011. The study adopts descriptive, correlational and inferential statistics and employs multiple linear regression analysis in analyzing the secondary data collected from 24 DMBs and determining their survival, growth, sustainability. The study finds that: there is significant positive relationship between liquidity management and the performance of DMBs in Nigeria; positive correlation between return on equity and liquidity management variables (liquidity and cash reserve ratios) while the relationship between liquidity management and loan to deposit ratio is negative. The key results however indicate that only DMBs with optimum liquidity were able to maximize returns effectively. The study therefore concludes that illiquidity and excess liquidity poses a major problem to the management operations of DMBs and recommends that optimum liquidity model should be adopted by the Board and top management to ensure efficiency and effectiveness in its liquidity management process.

Nabeel and Hussain (2017) examines liquidity management and its impacts on banks profitability in Pakistan from 2006 to 2015. The study adopts correlation, descriptive statistics research design and employed regression techniques analyzing secondary data from 10 banks. The quick ratio, current ratio, cash ratio, interest coverage ratio and capital adequacy ratios are proxies for liquidity management and returns on asset, returns on equity, and earnings per share are proxies for profitability. The research findings were however mixed for liquidity management proxies impact on the banks' profitability. The study finds a positive relationship between liquidity management (proxy by interest coverage ratio, capital adequacy ratio and quick ratio) and the banks' profitability while there was a negative relationship between liquidity management (proxy by cash ratio and current ratio) and the banks' profitability.

Okaro and Nwakoby (2016) investigates the effects of liquidity management on performance of Deposit Money Banks (DMBs) in Nigeria from 2000 to 2015. The study use secondary data collated from the CBN statistical bulletin and NDIC annual publications for 16 years and employs Ordinary Least Square in analyzing the data. Liquidity ratio, Loan to deposit ratio, Loan to total assets, Assets utilization, and Cash to deposit ratio were proxies for liquidity management while Return on Assets, Return on Equity, and Net Interest Margin were proxies for profitability. The study finds a negative and significant relationship between liquidity ratio and DMBs profitability and a positive and significant relationship between cash to deposit ratio and DMBs profitability. The study therefore recommends that: DMBs should employ reasonable measures in the management of liquidity such as lending and discounting bills instead of keeping excessive liquidity to meet customers' demands such as unexpected withdrawals; and the need for DMBs to invest excess liquidity in available investments opportunities at various degrees of maturities in order to increase profitability and obtain optimal benefits derived from the time value of money.

Olarewaju and Adeyemi (2015) examines the casual relationship between liquidity and profitability of Deposit Money Banks (DMBs) in Nigeria. A sample size of 15 DMBs were selected from the existing 19 quoted DMBs. The study employs Pairwise Granger Causality to test the presence and direction of causality between the banks' liquidity and profitability. The study finds that: there was no causal relationship (both unidirectional and bidirectional) between liquidity (LODEP) and profitability (ROE) for Guaranty Trust bank, Zenith bank, Sterling bank, Diamond bank, IBTC, Unity bank, UBA, Fidelity bank, Wema bank, Union bank, and Eco bank; while there is causal relationship between the variables running from 
liquidity to profitability for Skye bank, First bank, Access bank and FCMB. The study recommends that the apex bank (Central Bank of Nigeria) should ensure close supervision and monitoring of DMBs that they maintain liquidity adequate to support and strengthen financial sector stability.

Ibe (2015) investigates the impact of liquidity management on the profitability of banks in Nigeria. The study randomly selected a sample of three banks as representative of the entire banking industry in Nigeria. Cash and short-term fund, bank balances, treasury bills and certificates are use as proxies for liquidity management while profit after tax is the proxy for profitability. The study employs Elliot Rothenberg Stock (ERS) to test for the non-stationarity of the variables while regression analysis is use to test the hypothesis. The study finds that liquidity management was a crucial problem in the Nigerian banking industry and recommends that banks should engage competent and qualified personnel with the requisite skills to develop polices and strategies to ensure a balance between optimal level of liquidity and profit maximization.

\section{Liquidity Management and Bank Performance}

Kumar (2008) posits that management of liquidity risks is fundamental to bank business as every transaction or commitment has implications for its liquidity. Similarly, Nwaezeaku (2008) defined liquidity as the degree of convertibility to cash or the ease with which any asset can be converted to cash (sold at a fair market price). According to Choudhry (2011) liquidity management refers to the funding of deficits and investment of surpluses, managing and growing the balance sheet, as well as ensuring that the bank operates within regulatory and stipulated limits.

European Central Bank (ECB) (2010) describes bank performance as the capacity of a bank to generate sustainable profits. Bikker (2010) identifies costs, efficiency, profits and market structure as the main drivers of bank performance and returns on Assets (ROA), return on equity (ROE) and net interest margin as the measures of bank's performance or profitability.

Banks (2014) argues that to achieve effective liquidity management and profitability, there must be an uninterrupted endeavour of ensuring that a balance exists between liquidity, profitability and risk. This view is supported by Landskroner and Paroush (2011) who argues that in managing assets and liabilities the period of uncertainties in cash flows, cost of funds and return on investments, banks must establish the trade-off between risk, return and liquidity.

Several studies have been conducted on the nexus between liquidity and bank performance, but the findings have been mixed with some inconclusive. Some of the studies include: Olagunju, David and Samuel (2012) finds a positive significant relationship between liquidity and profitability and concluded that there is a bi-directional relationship between the variables where the profitability in commercial banks is significantly influenced by liquidity and viceversa. In contrast, Molyneux and Thornton (1992) finds an inverse relationship between bank profitability and liquidity arguing that banks hold liquid assets as an obligation to the requirements imposed by regulatory authorities.

Shen, Chen, Kao, and Yeh (2010) finds that in market-based financial system liquidity risk is positively related to net interest margin an indication that banks with high levels of illiquid 
assets receive higher interest income. This was in contrast with their earlier finding on the relationship with net interest margin that liquidity risk is negatively related to return on average assets and inversely related to return on average equity. They argue that banks with illiquid assets incur higher funding cost in the market in raising money to meet the funding gap. They found no relationship between liquidity risk and performance of banks because of the intermediation role they play and are therefore not affected by liquidity risk.

Demirgüç-Kunt and Huizinga (1999) found positive relationship between loans to total assets and the net interest margins and also established an inverse relationship between the net interest margin and before tax profits. Though their results were inconclusive.

Ben Naceur and Kandil (2009) finds that banks' liquidity does not determine returns on assets or equity significantly in their study on cost of intermediation in the post capital regulation period which they which include; higher capital-to-assets ratios, an increase in management efficiency, an improvement of liquidity and a reduction in inflation.

\section{METHODOLOGY}

The data use in this study include: Liquidity ratio (LR), Loan to deposit ratio (LDR), Cash reserve ratio (CRR) and deposit ratio (DR) as proxies for Liquidity Management, while return on assets (ROA), return on equity (ROE) and return on net interest margin (NIM) are the proxies for financial performance (Profitability). The data were extracted from the Central Bank of Nigeria reports and the annual reports banks, sample covered the period 2010-2018 from five banks selected from the population of banks listed on the Nigerian stock exchange.

The study adopts with modification, the model of Kargi (2011) which measured profitability using Return on Asset (ROA) as a function of ratio of Non-performing loans to Loans \& Advances (NPL/LA) and ratio of Total Loans and Advances to Total deposit (LA/TD) as indicators of credit risk. This study however improved on the model by incorporating two other metrics of measuring deposit money bank performance. They are return on equity and net interest margin. The choice of these three financial performances is because assets, equity and interest rate are critical to the wholesome evaluation of the financial performance of banks.

Therefore, the functional form of the model for the study becomes;

$R O A=f(L Q R, L D R, C R R, D R)$

$R O E=f(L Q R, L D R, C R R, D R)$

$N I M=f(L Q R, L D R, C R R, D R)$

Where:

$R O A=$ Return on Assets

$R O E=$ Return on Equity

$N I M=$ Net Interest Margin

$L Q R=$ Liquidity Ratio

$L D R=$ Loan-to-deposit Ratio

$C R R=$ Cash Reserve Ratio

$D R=$ Deposit Rate

The implicit form of the model is expressed 
$R O A=\alpha_{0}+\alpha_{1} L Q R+\alpha_{2} L D R+\alpha_{3} C R R+\alpha_{4} D R+\mu_{1}$
$R O E=\beta_{0}+\beta_{1} L Q R+\beta_{2} L D R+\beta_{3} C R R+\beta_{4} D R+\mu_{2}$
$N I M=\phi_{0}+\phi_{1} L Q R+\phi_{2} L D R+\phi_{3} C R R+\phi_{4} D R+\mu_{3}$

Where:

$\alpha_{1 \_} \alpha_{4}, \beta_{1 \_} \beta_{4}$ and $\phi_{1 \_} \phi_{4}$ are the parameter estimates or coefficients of models 4,5 and 6 respectively. $\alpha_{0}, \beta_{0}$ and $\phi_{0}$ are the intercept terms of models 4,5 and 6 respectively and $\mu_{1}$ ,$\mu_{2}$ and $\mu_{3}$ are the error or random terms of the respective models.

It is expected on a priori that, $\alpha_{1_{-}} \alpha_{4}, \beta_{1_{-}} \beta_{4}$ and $\phi_{1_{-}} \phi_{4}$ will be positively signed.

\section{RESULTS AND FINDINGS}

\section{Result of the Constant Effect Model}

The major assumption under this model is that all coefficients are constant across time period and individual banks.

The Panel Least Squares results of the three models are given below:

Table 4.1: Pool Effect Model Estimates.

\begin{tabular}{|c|c|c|c|c|c|}
\hline $\begin{array}{l}\text { Dependent } \\
\text { Variable }\end{array}$ & $\begin{array}{l}\text { Independent } \\
\text { Variables }\end{array}$ & Coefficients & Std. Error & t-statistic & Prob. \\
\hline \multicolumn{6}{|c|}{ EFFECT OF LIQUIDITY MANAGEMENT ON RETURN ON ASSETS } \\
\hline & LQR & 0.018894 & 0.067955 & 0.278041 & 0.7832 \\
\hline \multirow[t]{3}{*}{ ROA } & LDR & -0.016143 & 0.138652 & -0.116430 & 0.9082 \\
\hline & DR & 0.763370 & 1.684781 & 0.453097 & 0.6542 \\
\hline & CRR & -0.163905 & 0.280625 & -0.584072 & 0.5642 \\
\hline $\begin{array}{l}\text { R-Squared } \\
0.065\end{array}$ & $\begin{array}{l}\text { Adj R-Sqr - } \\
0.043\end{array}$ & $\begin{array}{ll}\text { S.E } & \text { Reg. } \\
3.423 & \end{array}$ & $\begin{array}{ll}\text { DW } & \text { Stat } \\
2.29 & \\
\end{array}$ & & \\
\hline \multicolumn{6}{|c|}{ EFFECT OF LIQUIDITY MANAGEMENT ON RETURN ON EQUITY } \\
\hline & LQR & 0.011783 & 0.574190 & 0.020521 & 0.9838 \\
\hline \multirow[t]{3}{*}{ ROE } & LDR & -0.065265 & 1.171543 & -0.055708 & 0.9560 \\
\hline & DR & 4.640293 & 14.23558 & 0.325964 & 0.7471 \\
\hline & CRR & -1.707105 & 2.371147 & -0.719949 & 0.4780 \\
\hline $\begin{array}{l}\text { R-Squared } \\
0.088\end{array}$ & $\begin{array}{l}\text { Adj R-Sqr - } \\
0.017\end{array}$ & $\begin{array}{ll}\text { S.E } & \text { Reg. } \\
28.925 & \end{array}$ & $\begin{array}{ll}\text { DW } & \text { Stat } \\
2.10 & \\
\end{array}$ & & \\
\hline \multicolumn{6}{|c|}{ EFFECT OF LIQUIDITY MANAGEMENT ON NET INTEREST MARGIN } \\
\hline & LQR & 0.052986 & 0.032795 & 1.615662 & 0.1182 \\
\hline \multirow[t]{3}{*}{ NIM } & LQR & -0.120603 & 0.066913 & -1.802383 & 0.0831 \\
\hline & DR & 1.956396 & 0.813070 & 1.906182 & 0.0535 \\
\hline & CRR & -0.233812 & 0.135429 & -1.726452 & 0.0961 \\
\hline $\begin{array}{l}\text { R-Squared } \\
0.325\end{array}$ & $\begin{array}{ll}\text { Adj } & \text { R-Sqr } \\
0.248 & \end{array}$ & $\begin{array}{ll}\text { S.E } & \text { Reg. } \\
1.652 & \end{array}$ & $\begin{array}{ll}\text { DW } & \text { Stat } \\
2.08 & \end{array}$ & & \\
\hline
\end{tabular}

Source: Extracts from Eviews 9.0 Output 
The results of the panel data for the three models show that all the coefficients are individually statistically insignificant both at $1 \%$ and $5 \%$ level of significance. The slope coefficients of liquidity ratio (LQR) and Deposit Rate (DR) have the expected positive signs. Similarly, the coefficients of loan to deposit rate (LDR) and cash reserve rate (CRR) also have the expected negative sign. The $R^{2}$ adjusted is relatively low for all the three models. That is $0.043,0.017$ and 0.248 for the first, second and third models respectively. The estimated Durbin Watson statistics is relatively high, suggesting that there is no problem of autocorrelation in the data. The intercept value is negative (not significant). By assumption the intercept value is the same for all the 5 banks. Also, the slope coefficients of the three variables are assumed to be identical for all five banks

\section{Hausman Test for the Choice between Fixed Effect and Random Effect Model}

The Hausman test is a test that compares the fixed and random effect models. If both fixed and random effects turn out significant, Hausman test will give you a good idea when choosing one between the two. The null is that the two estimation methods are both satisfactory and that therefore they should yield coefficients that are "similar". The alternative hypothesis is that the fixed effects estimation is justify and the random effects estimation is not; if this is the case, then we would expect to see differences between the two sets of coefficients. The Hausman Test for the three models is presented in the Table 4.2.

Table 4.2 Hausman Test

\begin{tabular}{|l|l|l|l|l|}
\hline & Test Summary & Chi-Square & d.f & Prob. \\
\hline Model 1 & Cross-section random & 8.587445 & 4 & $\begin{array}{l}0.011 \\
2\end{array}$ \\
\hline Model2 & Cross-section random & 8.254455 & 4 & $\begin{array}{l}0.012 \\
5\end{array}$ \\
\hline Model 3 & Cross-section random & 15.087453 & 4 & $\begin{array}{l}0.000 \\
0\end{array}$ \\
\hline
\end{tabular}

Source: Extract from Eviews 9.0 output

The result of the Hausman test in table 4.2 reveals that the null hypothesis is rejected in favour of the alternative implying that the fixed effect estimation is most appropriate to use in estimating the effect of liquidity management on return on assets (ROA), return on equity (ROE) and net interest management (NIM) for the five banks.

\section{The Fixed Effect Model (FEM) - Cross Sectional Specific}

In the basic fixed effects model, the effect of each predictor variable (i.e., the slope) is assumed to be identical across all the groups (banks), and the regression merely reports the average within-group effect. One way to take into account the individuality of each bank is to let the intercept vary for each bank but still assume that the slope coefficients are constant across the banks. The term "Fixed Effect "is due to the fact that although the intercept may differ across individuals (that is, the five banks), each individual bank's intercept does not vary over time. That is, it is time invariant. This is the major assumption under this model. That is, while the intercept is cross-sectional variant, they are time invariant. The results of the Fixed Effect Model under this assumption for the three models are presented in Table 4.3. 
Table 4.3: Fixed Effect Model Estimates.

\begin{tabular}{|c|c|c|c|c|c|}
\hline $\begin{array}{l}\text { Dependent } \\
\text { Variable }\end{array}$ & $\begin{array}{l}\text { Independent } \\
\text { Variables }\end{array}$ & Coefficients & Std. Error & t-statistic & Prob. \\
\hline \multicolumn{6}{|c|}{ EFFECT OF LIQUIDITY MANAGEMENT ON RETURN ON ASSETS } \\
\hline & $\mathrm{C}$ & -23.84301 & 12.02565 & -1.982680 & 0.0606 \\
\hline & LQR & 0.182669 & 0.121002 & 1.509627 & 0.1460 \\
\hline \multirow[t]{3}{*}{$\mathrm{ROA}$} & LDR & -0.042679 & 0.134562 & -0.317172 & 0.7542 \\
\hline & DR & 3.670570 & 2.190221 & 1.675890 & 0.1086 \\
\hline & CRR & -0.713120 & 0.387520 & -1.840217 & 0.0799 \\
\hline $\begin{array}{l}\text { R-Squared } \\
0.874\end{array}$ & $\begin{array}{ll}\text { Adj } & \text { R-Sqr } \\
0.828 & \\
\end{array}$ & $\begin{array}{ll}\text { S.E } & \text { Reg. } \\
0.306 & \end{array}$ & $\begin{array}{ll}\text { DW } & \text { Stat } \\
2.49 & \\
\end{array}$ & $\begin{array}{l}\text { F-Stat. } \\
9.104\end{array}$ & $\begin{array}{l}\mathrm{P} \text { (F.Stat.) } \\
0.0025\end{array}$ \\
\hline \multicolumn{6}{|c|}{ EFFECT OF LIQUIDITY MANAGEMENT ON RETURN ON EQUITY } \\
\hline & $\mathrm{C}$ & -113.8849 & 104.0130 & -1.094910 & 0.2860 \\
\hline & LQR & 0.974538 & 1.046582 & 0.931162 & 0.3624 \\
\hline \multirow[t]{3}{*}{ ROE } & LDR & -0.061482 & 1.163860 & -0.052826 & 0.9584 \\
\hline & DR & 18.52638 & 18.94379 & 0.977966 & 0.3392 \\
\hline & CRR & -4.330400 & 3.351758 & -1.291979 & 0.2104 \\
\hline $\begin{array}{l}\text { R-Squared } \\
0.715\end{array}$ & $\begin{array}{ll}\text { Adj } & \text { R-Sqr } \\
0.704 & \\
\end{array}$ & $\begin{array}{ll}\text { S.E } & \text { Reg. } \\
0.592 & \end{array}$ & $\begin{array}{ll}\text { DW } & \text { Stat } \\
2.18 & \\
\end{array}$ & $\begin{array}{l}\text { F-Stat. } \\
7.023\end{array}$ & $\begin{array}{l}\text { P(F.Stat.) } \\
0.0049\end{array}$ \\
\hline \multicolumn{6}{|c|}{ EFFECT OF LIQUIDITY MANAGEMENT ON NET INTEREST MARGIN } \\
\hline & $\mathrm{C}$ & 1.491608 & 5.730092 & 0.260311 & 0.7972 \\
\hline & LQR & 0.040376 & 0.057656 & 0.700288 & 0.4914 \\
\hline \multirow[t]{3}{*}{ NIM } & LDR & -0.118943 & 0.064117 & -1.855085 & 0.0777 \\
\hline & DR & 1.774522 & 1.043617 & 1.700358 & 0.1038 \\
\hline & CRR & -0.199453 & 0.184649 & -1.080174 & 0.2923 \\
\hline $\begin{array}{l}\text { R-Squared } \\
0.744\end{array}$ & $\begin{array}{ll}\text { Adj } & \text { R-Sqr } \\
0.716 & \end{array}$ & $\begin{array}{ll}\text { S.E } & \text { Reg. } \\
0.575 & \end{array}$ & $\begin{array}{ll}\text { DW } & \text { Stat } \\
2.24 & \end{array}$ & $\begin{array}{l}\text { F-Stat. } \\
8.6757\end{array}$ & $\begin{array}{l}\text { P(F.Stat.) } \\
0.0037\end{array}$ \\
\hline
\end{tabular}

Source: Extract from Eviews 9.0 Output

Comparing this regression result with the one in Table 4.1. It is evident that, the coefficients of the independent variables for all the models are highly significant as the probability values of the estimated " $t$ " statistics are smaller. The intercept values of the five banks are statistically the same as shown below.

The major assumption under this model is that all coefficients are fixed across time period and individual bank. That is, in the basic fixed effects model, the effect of each predictor variable (i.e., the slope) is assumed to be identical across all the groups, and the regression merely reports the average within-group effect.

The intercept value is negative (not significant). By assumption the intercept value is the same for all the 5 banks for each of the models. Also, the slope coefficients of the three variables are assumed to be identical for all the five banks. Obviously, these are highly restricted assumptions. This result obviously distorts the true picture of the relationship between bank performance and all the independent variables across the five banks. 
For the first model (effect of liquidity management on return on assets), the slope coefficients of liquidity ratio (LQR) and Deposit Rate (DR) have the expected positive signs and the coefficients of loan to deposit rate (LDR) and cash reserve rate (CRR) have the expected negative sign. A unit increase in LR and DR will lead to increase in ROA by 0.182669 and 3.67057 respectively. On the other hand, a unit increase in LDR and CRR will lead to decrease in ROA by 0.04268 by 0.71312 respectively.

The $R^{2}$ adjusted for the first model is 0.828 . The implication therefore is that, $82.8 \%$ of the variation in the dependent variable (ROA) for all the five banks is explained by the independent variables (LQR, LDR, DR and CRR). This value is relatively high enough to conclude that the model has goodness of fit.

For the second model (Effect of liquidity management on return on equity), the slope coefficients of liquidity ratio (LQR) and Deposit Rate (DR) have the expected positive signs and the coefficients of loan to deposit rate (LDR) and cash reserve rate (CRR) have the expected negative sign. A unit increase in LR and DR will lead to increase in ROE by 0.974538 and 18.52638 respectively. Also, a unit increase in LDR and CRR will lead to decrease in ROE by 0.06148 and 4.3304 respectively.

The $R^{2}$ adjusted for the second model is 0.704 . The implication therefore is that, $70.4 \%$ of the variation in the dependent variable (ROE) for all the five banks is explained by the independent variables (LQR, LDR, DR and CRR). This value is relatively high enough to conclude that the model has goodness of fit. This value is relatively high enough to conclude that the model has goodness of fit.

The estimated Durbin Watson statistics for all the three variables are relatively high, suggesting that there is no problem of autocorrelation in the data sets for the three models. Also, the relative high values of the F-statistics coupled with their low probability values indicated that, all the models are statistically significant.

For the third model (Effect of liquidity management on Net Interest Margin), the slope coefficients of liquidity ratio (LQR) and Deposit Rate (DR) have the expected positive signs and the coefficients of loan to deposit rate (LDR) and cash reserve rate (CRR) have the expected negative sign. A unit increase in LDR and DR will lead to increase in NIM by 0.040375 and 1.774522 respectively while a unit increase in LDR and CRR will lead to a decrease in NIM by 0.11894 and 0.19945 respectively.

The $R^{2}$ adjusted for the third model is 0.716 . The implication therefore is that, $71.6 \%$ of the variation in the dependent variable (NIM) for all the five banks is explained by the independent variables (LQR, LDR, DR and CRR). This value is relatively high enough to conclude that the model has goodness of fit.

\section{DISCUSSIONS}

The study found out that, for the pooled effect model all the coefficients of the independent variables are statistically insignificant at 5\% level of significance. This point to the fact that, the effect of liquidity management (LDR, LQR, DR and CRR) on the financial performance of the five banks measured in terms of ROA, ROE and NIM may be by chance. Furthermore, the 
result of the Hausman Test for the choice between the Random effect and the Fixed effect indicated that, fixed effect estimation is most appropriate to use in estimating the effect of liquidity management on return on assets (ROA), return on equity (ROE) and net interest management (NIM) for the five banks. Using the fixed effect result in Table 4.3 for all the variables, the study found out that, liquidity ratio (LQR) and deposit rate (DR) have positive and significant effect financial performance of banks as measured by return on assets (ROA), return on equity (ROE) and net interest margin (NIM). This implies that, the more liquid the banks are, due to high liquidity ratio and deposit rate, the better their financial power to meet up with their financial obligations. On the other hand, the higher the cash reserve ratio and loan to deposit ratio, the lesser the ability of the amount of cash with the banks and the weaker their ability to meet up with their financial obligations.

\section{Implication to Research and Practice}

The study investigated the effects of liquidity management on financial performance of deposit money banks in Nigeria for the period 2010-2015. The study anchored on shiftability theory that boarder on banks financial performance and liquidity management. The data used for the study was from secondary sourced and was sourced from the Central Banks of Nigeria and from the Annual Financial reports of banks in Nigeria. The study made use of Panel regression analysis given that the date set for the study is both Cross-sectional and Time-series in nature. The choice between the Random effects and the fixed effects models was arrived at using the Hausman Test. The result of the fixed effects estimation indicates that, for all the banks, liquidity ratio and deposit rates have positive and significant effects on the financial performance of the banks as measured by return on assets, return on equity and net interest margin. On the other hand, the result reveals that loan to deposit ratio and cash reserve ratio have negative but significant effect on the financial performance of the banks as measured by return on assets, return on equity and net interest margin.

The study rejected all the three null hypotheses in favour of the alternative hypotheses with the conclusion that, liquidity management has significant effect on return assets (ROA) of banks in Nigeria, on return to assets (ROE) and on net interest margin in Nigeria respectively.

\section{CONCLUSION}

Arising from the findings, it is evident that an effective liquidity management has a positive impact on all the proxies of bank performance (returns on assets, returns on equity and net interest margin). This finding supports the findings of Olagunju, David and Samuel (2012); and Bassey (2017) in Nigeria.

The study concludes that the financial performance of the banks in Nigeria can be improved by the establishment of sound and robust liquidity management structure in place to ensure that adequate liquidity is maintained to meet matured and maturing obligations as they fall due.

The study therefore recommends that banks in Nigeria should establish a sound governance and risk management system such as Asset Liability Management Committees (ALCO) for liquidity management, develop strategies and policies for the management of liquidity that is well integrated in the banks risk management practices, establish Contingency Funding Plan that clearly articulate the steps to be taken to address liquidity shortfall during periods of stress 
or emergency, carryout active the monitoring of the liquidity funding needs of banks to avert any potential liquidity challenge that could trigger crisis is promptly addressed.

\section{Future Research}

This study recommends that, further researches on this topic should make use of a sample size of more than five banks and should use a time period of more than six years. This if properly done, may provide more robust findings for the purpose of policy implementation.

\section{REFERENCES}

Adalsteinsson, G. (2014). The Liquidity Risk Management Guide: From policy to pitfalls. Sussex: John Wiley and Sons.

Adeyinka, S. (2013). Capital Adequacy and Banks' Profitability: An Empirical Evidence from Nigeria, American International Journal of Contemporary Research 1(3) 10-29

Agbada, A. O. \& Osuji, C. C. (2013). The Efficacy of Liquidity Management and Banking Performance in Nigeria. International Review of Management and Business Research, 3(2) $57-72$

Anyanwu, J. C. (1993). Monetary Economics: Theory, Policy and Institutions. Benin City. Hybrid Professional Publishers Ltd,

Banks, E. (2014). Liquidity risk: Managing funding and asset risk. Hampshire: Palgrave Macmillan.

Bassey E.B., \& Ekpo U.N (2018). Liquidity Management in Nigerian Deposit Money Banks:

Issues, Challenges and Prognosis. International Journal of Economics, Commerce and Management, 6(5) 556-580

Bassey, E.D (2017). Liquidity Management and Performance of Deposit Money Banks in Nigeria 1986 - 2011: An Investigation. International Journal of Economics, Finance and Management Sciences. 5(3) 146-161

Basel Committee on Banking Supervision, (2008). Principles for Sound Liquidity Risk Management and Supervision. Bank for International Settlements. Press \& Communications

Ben Naceur, S., \& Kandil, M. (2009). The impact of capital requirements on banks' cost of intermediation and performance: The case of Egypt. Journal of Economics and Business, 61(1), 70-89.

Bhattacharyya, I. \& Sahoo, S. (2011). Comparative Statistics of Central Bank liquidity Management, Some insights, Economic research International, 3(2), 34-56.

Bikker, J. A. (2010). Measuring performance of banks: an assessment. Journal of Applied Business and Economics, 11(4), 141-159.

Bourke, P. (1989). Concentration and other Determinants of Bank Profitability in Europe, North America and Australia. Journal of Banking \& Finance, 13(1), 65-79.

Choudhry, M. (2011). An Introduction to Banking: Liquidity Risk and Asset and Liability Management.Sussex: John Wiley and Sons.

Demirgüç-Kunt, A., \& Huizinga, H. (1999). Determinants of commercial bank interest margins and profitability: some international evidence. The World Bank Economic Review, 13(2), 379-408. Drakos

Eljelly, A. (2004). Liquidity-Profitability Tradeoff: An Empirical Investigation in an Emerging Market. International Journal of Commerce \& Management. 14(2),48-61. 
Ibe, S. O. (2015). The Impact of Liquidity Management on the Profitability of Banks in Nigeria. Journal of Finance and Bank Management 1(1) 67-88

Kargi, H.S. (2011). Credit Risk and the Performance of Nigerian Banks, Ahmadu Bello University, Zaria.

Kehinde, O. P. (2013). An Empirical Investigation of the Liquidity-Profitability Relationship in Nigerian Commercial Banks. Journal of Economics and Sustainable Development, 6(4) 69-87

Loth, R. (2012). Liquidity Measurement Ratio: Current Ratio; Investopedia; www.investopedia.com

Landskroner, Y. \& Paroush, J. (2011) "Liquidity Risk Management, Structure, and Competition in Banking"The Capco Institute Journal of Financial Transformation. Article no.33, pp.113-120.

Molyneux, P., \& Thornton, J. (1992). Determinants of European bank profitability: A Note. Journal of Banking \& Finance, 16(6), 1173-1178.

Nabeel1, M. \& Hussain, S.M (2017). Liquidity Management and Its Impact on Banks Profitability: A Perspective of Pakistan. International Journal of Business and Management Invention 6(5) 28 -33

Naezeaku, N. C. (2006). Theories and Practice of Financial Management.Owerri. Ever Standard Publishing.

Ngwu, T. C. (2006). Bank Management. Owerri: Bob Publishers.

Niresh, J. A (2012). Trade-off Between Liquidity and Profitability. A Study of Selected Manufacturing Firms in Sri Lanka: Journal of Arts and Science and Commerce, 4 (2) 111-122

Nwankwo G. O. (1991). Bank Management Principles and Practices. Lagos: Malthouse Press Nwankwo, G. O. (1991). Prudential Regulations of Nigerian Banking. Lagos: University of Lagos.

Nzzotta, S. M. (2004.) Money, Banking and Finance: Theory and Practice. Owerri.

Obi-Nwosu, V. O., Okaro, C.S, Ogbonna, K.S., \& Atsanan, A.N (2017). Effect of Liquidity on

Performance of Deposit Money Banks. International Journal of Advanced Engineering and Management Research, 2(4) 1281-1290

Okaro, C.S. \& Nwakoby C. N. (2016). Effect of Liquidity Management on Performance of Deposit Money Banks

In Nigeria. 2000-2015, Journal of Policy and Development Studies 10(3) 156-169

Olagunju, A., David, A. O., \& Samuel, O. O. (2012). Liquidity Management and Commercial

Banks' Profitability in Nigeria. Research Journal of Finance andAccounting, 2(7-8), 24-38.

Olarewaju1, O.M. \& Adeyemi, O.K (2015). Causal Relationship between Liquidity and Profitability of

Nigerian Deposit Money Banks, International Journal of Academic Research in Accounting, Finance and Management Sciences 5(2) 165-171

Otekunrin, A.O, Fagboro, G.D, Nwanji,T.I , Asamu, F.F, Ajiboye, B.O \& Falaye, A.J (2019). and Bank

Performance of deposit money banks and liquidity management in Nigeria. Banks

Systems, 14(3) 144-161

ONyekwelu, U.L., Chukwuani, V.N. and Onyeka, V.N. (2018) Effect of Liquidity on Financial Performance of 
European Journal of Business and Innovation Research

Vol.8, No.4.pp. 30-44, July 2020

Published by ECRTD-UK

Print ISSN: 2053-4019(Print), Online ISSN: 2053-4027(Online)

Deposit Money Banks in Nigeria, Journal of Economics and Sustainable Development 9(4) 131-14

Pandey, I. M. (2005). Financial Management. Vikas Publishing House. PVT Ltd New Delhi.

Shen, C., Chen, Y., Kao, L. \& Yeh, C. (2010). Bank liquidity risk and performance. International Monetary Fund, Working Paper.

Uremadu, S. (2012). Bank Capital Structure, Liquidity and Profitability Evidence from the Nigerian Banking System. International Journal of Academic Research in Accounting, Finance and Management Sciences, 8(20)78-91 